Article

\title{
Sustainable, Smart and Muslim-Friendly Tourist Destinations
}

\author{
Pedro Cuesta-Valiño*(D), Fadoua Bolifa *(D) and Estela Núñez-Barriopedro $(\mathbb{D}$
}

Department of Economics and Business Management, University of Alcalá, 28802 Alcalá de Henares, Spain; estela.nunezb@uah.es

* Correspondence: pedro.cuesta@uah.es (P.C.-V.); fadoua.bolifa@edu.uah.es (F.B.)

Received: 29 January 2020; Accepted: 22 February 2020; Published: 27 February 2020

\begin{abstract}
Information and Communication Technology (ICT) tools are perfect for developing tourism. Several countries are making an effort to become smart and sustainable tourist destinations, making it easier for tourists to interact with their environment while at the same time improving the quality of life for local people. There are many studies of this process and the benefits it brings, although most of them approach the subject from a western traveler's point of view. This article aims to study the benefits of being a smart and Muslim-friendly tourist destination. An exploratory study was therefore carried out, including a bibliographical review of over one hundred secondary sources. We analyze the Muslim-friendly online services provided by nine destinations, and one of our principal conclusions is that these online services are of the greatest importance for a destination to be truly Muslim-friendly. We also conclude that such services allow companies to design tailored proposals and promote them through digital channels aimed at Muslim people.
\end{abstract}

Keywords: smart tourism; IT applications; Muslim-friendly; halal tourism; sustainability; tourist destination

\section{Introduction}

The expansion of the Internet is accelerating the use of information technologies, intelligence and innovation. In fact, the rate of expansion is such that it is reconfiguring all sectors of the economy $[1,2]$. The tourism sector must also respond to this challenge and aim to provide a tailored offering [3-5].

Nowadays, tourists are ever more connected, informed and demanding, since they can access highly detailed information [6]. Before they buy, they can compare alternatives on websites or mobile apps. To summarize, it can be said that we have a new generation of tourists who oblige destinations to evolve in this same direction in order to meet their needs and expectations [7].

Until the last two decades, the tourism industry was viewed from a western perspective [8]. This perspective has taken little account of other peoples and cultures [8-10]. Little has been done thus far to meet the needs of other groups who come from different cultures and ways of life, but if smarter, more sustainable tourism is to be offered, these needs must be taken into account [11-14]. In fact, people all over the world are travelling more than ever. Specifically, 1,400 million people travelled to another country for tourism purposes in 2017 [15]. Despite this, there is still a major challenge for managers in the tourism industry: to learn about the tourist's home culture $[10,16]$ in order to offer them goods and services that will make them feel at home [17,18].

Then again, it should be pointed out that a quarter of the world's population is Muslim, and their religion governs their way of life $[19,20]$. These people evidently constitute a significant market share for the tourism industry [21,22].

The Muslim-friendly tourist destinations literature gap was examined to answer the following questions: what Muslim-friendly services must a destination offer for it to be considered a 
Muslim-friendly destination? What are currently the smartest and most sustainable Muslim-friendly destinations? Are these destinations Muslim-friendly, smart and sustainable over time?

Consequently, one of the principal objectives of this work is to analyze how destinations are ever smarter and more sustainable through offering Muslim-friendly tourism, which requires them to study and adapt tourism services to the religious requirements of the Muslim market segment] [23-25]. Another aim is to study the Muslim-friendly digital offering of the best of the top 20 sustainable smart tourist destinations in the Muslim-friendly ranking for 2017-2018.

This study considers sustainable smart and Muslim-friendly tourist destinations as a new contribution to the literature. The following research provides a conceptual framework, which is applied to the top sustainable smart tourist destinations. This may be applied to other tourism destinations that wish to become more digitally oriented and offer sustainable smart tourist services aimed at the Muslim market segment.

\section{Theory}

The following section provides a conceptual framework for sustainable smart and Muslim-friendly tourist destinations, which is therefore structured as follows. Firstly, we explain what we mean by smart, sustainable tourist destinations. Secondly, the culture, religion and segmentation variables are studied. Thirdly, the characteristics of the Muslim market segment are analyzed. Finally, the criteria for considering that a destination is Muslim-friendly are examined.

\subsection{Sustainable, smart, tourism destinations}

Information and Communication Technologies (ICTs) have revolutionized the hospitality and tourism industries [26]. As a result of the use of ICT, tourists are increasingly aware of the characteristics of the tourism offering and seek greater customization [27-30] (in addition, they are acquiring greater power through the use of technologies to co-create value with other stakeholders of that destination [31]).

Destinations are therefore working to become intelligent and sustainable tourist destinations by making good use of technologies to inform tourists about the destination, and specifically the services available, thus improving the traveler's experience, benefitting the tourism industry, and improving the quality of life for local residents [6,32-35].

Today, there are intelligent guides that provide comprehensive tourist information on travel-related services such as where to eat, transportation, hotel reservations and travel guides to the destinations [36,37].

People who are more accustomed to using their phones at home have more interest in doing so while traveling, and are more likely to do so [38,39]. This helps them save time [40], and therefore influences both their satisfaction and the relationship between mobility and satisfaction [41]. Tourists use mobile devices to plan, buy and improve their travel experiences [42,43]. There has been a growth in the use of mobile applications in the industry. This is a significant support for smart tourist destinations, making travel more functional and practical [44]. One of the potential uses of mobile information services is to support the search for tourist information on the site [45].

Applications are useful for tourists, but they are also of great importance for destinations. In fact, Big Data resulting from user-generated content and real-time analysis and synchronization of this data have become the main drivers of the value-creation process for an intelligent destination $[44,46]$. On the one hand, they make it possible for tourism profiles to be defined in more detail, both their sociodemographic profiles and their preferences, feelings and attitudes. These data are very useful for creating tourist services that better meet the needs of tourists [47]. This may allow companies to offer personalized experiences in the hotel industry, and it has become of the highest importance for companies that want to attract consumers in a more personalized way [48-50].

\subsection{Culture and Religion and Segmentation Variables}

Although the world seems ever more interconnected by the technological revolution, cultural differences persist. Some aspects of consumer habits seem to be deeply rooted in culture, and are 
thus resistant to change [51-53]. The traditional segmentation criteria, which involve geographic, sociodemographic, psychographic and behavioral components, need to be revised and new criteria introduced [54]. Although religion and culture are market segmentation variables [55-57], in general it seems that a specific app is required, within the world of tourism marketing, that is more in line with religion. To summarize, people travel with all their cultural-religious baggage, and cannot discard it when holidaying in destinations that are culturally different [58]. In the case of Muslims, religion is not a question of certain isolated religious practices; rather it is a way of life that affects several aspects of their lives [59-64]. The term halal refers to products and services that are suitable for Muslims [65], and Muslim-friendly refers to those companies and institutions which offer some services that are suitable for Muslims [66,67]. Muslims are very unlikely to go on a holiday that involves leaving their comfort zones to visit other areas where their sensibilities are not taken into consideration [68]. The Muslim-friendly tourism option may be an incentive, an approach and an attraction for Muslims who want to discover other places where they can have fun without contravening their religious and cultural principles $[22,23,69]$.

\subsection{Characteristics of the Muslim Market Segment}

It should be pointed out that $24 \%$ of the world's population is Muslim [70]. This equates to around 1.7 billion people for whom their religion governs their way of life $[19,20]$. These people evidently constitute a significant market share for many industries [57], including tourism [16,17].

The Muslim travel market shows continuous growth in terms of both the amount spent and the number of Muslim arrivals worldwide. The Muslim segment is very loyal to those products and services that are tailored to meet their religious requirements [71-73].

The Muslim population is younger than the global average [70]. There are about one billion young people who are better educated and demand products and services that respect their religious beliefs [70,74].

Young Muslims can be considered to be one of the key motors for growth in Muslim travel, since young Muslim tourists, when compared with older Muslims, have higher incomes and are prepared to spend them, are hyper-connected, seek out information on halal products, brands and trips, are influenced by opinions on digital media, like to share their own opinions, and leave comments on social networks about halal products and services $[75,76]$.

Like other young people, they are very attached to new technologies [77-79], use their smartphones for multiple purposes and use them throughout the various stages of their trip $[31,41,80,81]$. They download apps, such as apps that provide prayer times, especially in non-Muslim countries where there are no muezzins making the call to prayer over loudspeakers on mosques; apps that indicate the direction of Mecca so that the traveler can pray facing the right direction [82] (Fakhruroji 2018); and apps that geo-locate restaurants and places of worship. All these apps make life easier for Muslim travelers. These platforms are enriched by user comments [83].

The use of IT applications is affected by the users' culture [84], and in tourism, that variable also affects users' confidence in websites $[85,86]$. In the case of Muslims, they usually consult religious apps as part of everyday life, to learn or practice their religion, or to read verses of the Quran $[87,88]$. Many Muslims also search for websites and apps for geo-locating Muslim-friendly places and thus check whether their stay at a particular destination will make it easier or harder to practice their religion [89].

\subsection{Criteria for evaluating destinations as Muslim-Friendly}

There are many studies that demonstrate the importance of the availability of halal food for Muslims when it comes to choosing their tourism destinations [21,90-93]. Several countries are therefore working to satisfy that requirement by promoting and disseminating their Muslim-friendly offerings through online channels aimed at the Muslim market segment, such as websites and applications, 
in order to ensure that their messages reach Muslim tourists [94]. They thus assist Muslim tourists and consumers in making decisions, and also ensure that their visit is more satisfactory [89].

A Muslim-friendly destination is one that is aware of the needs of the Muslim market segment and its religious sensibilities and provides appropriate products and services [24,95].

The institution that studies this tourism is Mastercard-CrescentRating, which is the most significant authority on Muslim-friendly halal tourism. CrescentRating has been studying tourist destinations since 2011, and since its association with Mastercard they have been producing the Global Muslim Travel Index (GMTI), which ranks 130 destinations. Of these, 48 destinations are in countries belonging to the Organization of Islamic Cooperation (OIC) and 82 are in non-OIC countries. The aim is to evaluate these tourist destinations and rank them from more to less Muslim-friendly based on various criteria and factors, which they adapt according to the needs of the market and the latest trends. To this end, it uses the ACES (Access, Communications, Environment and Services) criteria created by CrescentRating, which provide a guided framework to enable destinations to better understand the key aspects of halal travel. The four key factors, which are evaluated using quantitative data, are:

(1) Ease of access to the destination

(2) Internal and external communication by the destination

(3) Environment at the destination

(4) Services provided by the destination

The Global Muslim Travel Index (GMTI) is now the main reference source for the industry. It provides in-depth market insights to help all stakeholders benefit from the growth of the Muslim market segment [96]. The GMTI makes it possible for destinations and hospitality services to connect effectively with Muslims. Since this annual index was created, its criteria and sub-criteria have evolved in keeping with the development of the Muslim travel market.

In 2018, four new sub-criteria were added to the ACES criteria to take account of the destination's levels of innovation and sustainability.

\section{Material and Methods}

In order to answer to the questions and achieve the aims of this research, an exploratory study has been carried out including a review of the principal literature in the field of Muslim-friendly tourism destinations.

Specifically, over a hundred studies have been reviewed in order to identify the state of the art and develop the framework.

The following academic databases were used for the literature search: Dialnet, EBSCO, Host, Google Scholar, Scopus, ProQuest and Web of Science (WOS). Key words included terms such as smart tourism; IT applications; Muslim-friendly; halal tourism; sustainability; tourist destination; Muslim market segmentation; and Global Muslim Travel Index (GMTI). Additionally, reports and websites were reviewed.

To assess the importance of ICT-based services aimed at the Muslim market segment when considering a friendly destination for Muslims, this work studies the extent to which these digital approaches to the Muslim segment affect the position of a country in the 2018 GMTI index ranking when compared to the 2017 GMTI index. One important difference between these indices is that innovation criteria were included in the 2018 GMTI index (see Table 1).

For this study, nine countries were selected for which the Muslim population does not exceed $6.5 \%$ in order to ensure that the services studied had been created to attract Muslim tourists rather than designed for the local population. The following criteria were also applied:

- Countries that have maintained their positions at the top of the ranking

- Countries that have decreased or increased considerably in the ranking

The offer of Muslim-friendly technology provided by each of these nine selected destinations is investigated, listing the most relevant web pages and mobile applications that target the Muslim 
market segment, the agency that created them and the functions that provided and edit a table with all the information collected (see Table 2).

\section{Results}

The countries that provide more Muslim-friendly digital services have kept their high positions in the rankings or have gone up by several positions (see Table 1).

Table 1. Comparison of 2018 Top 20 Non-Organization of Islamic Cooperation (OIC) destinations with corresponding performance in 2017.

\begin{tabular}{cccccc}
\hline Rank & Top 20 Non OIC 2018 & Score & Rank & Top 20 Non OIC 2017 & Score \\
\hline 6 & Singapore & 66.2 & 10 & Singapore & 67.3 \\
16 & Thailand & 56.1 & 18 & Thailand & 61.8 \\
22 & United Kingdom & 53.8 & 20 & United Kingdom & 60 \\
25 & Japan & 51.4 & 30 & South Africa & 53.6 \\
27 & Taiwan & 49.6 & 31 & Hong Kong & 53.2 \\
27 & Hong Kong & 49.6 & 32 & Japan & 52.8 \\
32 & South Africa & 47.7 & 33 & Taiwan & 52.4 \\
35 & Germany & 45.7 & 34 & France & 52. \\
36 & France & 45.2 & 36 & Spain & 48.8 \\
37 & Australia & 44.7 & 37 & United States & 48.6 \\
38 & Switzerland & 44.0 & 39 & Germany & 48.2 \\
39 & Spain & 43.5 & 40 & India & 47.6 \\
41 & South Korea & 43.1 & 41 & Sri Lanka & 47.5 \\
42 & Philippines & 42.8 & 42 & Australia & 46.7 \\
45 & Canada & 42.1 & 43 & Philippines & 46.5 \\
45 & Russian Federation & 42.1 & 44 & Russian Federation & 46.5 \\
47 & China & 41.8 & 45 & China & 45.9 \\
47 & Ireland & 41.8 & 47 & South Korea & 45.5 \\
49 & India & 41.6 & 49 & Canada & 45.1 \\
51 & New Zealand & 41.2 & 51 & Belgium & 44.8 \\
\hline
\end{tabular}

Source: Own elaboration, using data from the Global Muslim Travel Index 2017, 2018.

For example, Thailand has retained its second position and provides a wide range of Muslim-friendly digital services, some created by the official tourism body and others by private, internationally active companies. The United Kingdom is still third because it has extensive Muslim-friendly online services (see Tables 1 and 2). 
Table 2. The online services provided by the destinations studied and their positions in the Global Muslim Travel Index (GMTI) ranking in 2017 and 2018.

\begin{tabular}{|c|c|c|c|c|c|}
\hline Country & $\begin{array}{l}\text { Ranking Position } \\
\text { Comparison }\end{array}$ & $\begin{array}{l}\text { Percentage of Muslims } \\
\text { in Population }\end{array}$ & $\begin{array}{l}\text { Apps Websites } \\
\text { Muslim-Friendly }\end{array}$ & Body & Function \\
\hline \multirow{6}{*}{ Thailand } & \multirow{6}{*}{$\begin{array}{l}2017 \text { 2nd } \\
2018 \text { 2nd }\end{array}$} & \multirow{6}{*}{$6 \%$} & Halal route App2016 & $\begin{array}{l}\text { The Tourism Authority of Thailand, with } \\
\text { the support of several of the country's } \\
\text { institutions }\end{array}$ & Reserve halal hotels through a travel agent or online \\
\hline & & & Grab Halal & The Tourism Authority of Thailand (TAT) & \multirow{2}{*}{$\begin{array}{l}\text { A list of } 300 \text { hotels, restaurants and take-away food outlets } \\
\text { The largest Muslim-friendly travel platform. Share and } \\
\text { review mosques, Halal restaurants, Halal food dishes, } \\
\text { attractions and ideas for trips. Kaaba direction finder, } \\
\text { prayer times, in-flight prayer time calculator. }\end{array}$} \\
\hline & & & $\begin{array}{l}\text { Halal Trip platform and App } \\
2015\end{array}$ & Acquired by CrescentRating in 2013 & \\
\hline & & & Halal booking & Founded in 2009 by private individuals & Platform for reserving Muslim-friendly accommodation \\
\hline & & & $\begin{array}{l}\text { Thailand Muslim-friendly } \\
\text { App }\end{array}$ & The Tourism Authority of Thailand & Search for restaurants, hotels, mosques \\
\hline & & & Thai Halal App & Halal certification body & Halal product search tool \\
\hline \multirow{4}{*}{ UK } & \multirow{4}{*}{$\begin{array}{l}20173 \text { rd } \\
20183 r d\end{array}$} & \multirow{4}{*}{$6.3 \%$} & Halal Dining Club app2016 & Halal Dining Club & $\begin{array}{l}\text { Over } 3500 \text { restaurants in several cities: London, Toronto, } \\
\text { Birmingham, Kowloon, Bangkok, New York, Manchester, } \\
\text { Paris. }\end{array}$ \\
\hline & & & $\begin{array}{l}\text { The Halal Monitoring } \\
\text { Committee Website and App }\end{array}$ & $\begin{array}{l}\text { The most trusted halal certification } \\
\text { organization in the UK, with the support } \\
\text { of over } 600 \text { Mosques }\end{array}$ & The country's halal-certified products and services \\
\hline & & & Halal Joints & Private investors & $\begin{array}{l}\text { Listing of } 560 \text { Halal Restaurants, available for other } \\
\text { countries }\end{array}$ \\
\hline & & & Halal Restaurants Finder App & Private investors & Restaurants, mosques and markets \\
\hline \multirow{7}{*}{ Japan } & \multirow{7}{*}{$\begin{array}{l}2017 \text { 6th } \\
2018 \text { th }\end{array}$} & \multirow{7}{*}{$0.15 \%$} & The Japan Muslim Guide & Japan Halal Business Association & $\begin{array}{l}\text { Information on accommodation, restaurants and mosques } \\
\text { for Muslim visitors to Japan }\end{array}$ \\
\hline & & & Halal Minds App 2013 & Private investors & Halal products in Japanese supermarkets \\
\hline & & & Kyoto Muslims 2014 & $\begin{array}{l}\text { Kyoto Convention \& Visitors Bureau } \\
\text { (KCVB) }\end{array}$ & A travel guide \\
\hline & & & Halal Gourmet Japan App & Halal Media Japan & $\begin{array}{l}\text { Find restaurants and mosques, has over } 897 \text { halal and } \\
\text { vegetarian restaurants }\end{array}$ \\
\hline & & & Halal Navi app & Private investors & $\begin{array}{l}\text { Accompanies Muslim tourists and facilitates their } \\
\text { itinerary through Japan, providing users with the } \\
\text { country's Muslim-friendly routes, the locations of the } \\
\text { Muslim-friendly restaurants and hotels and each prayer } \\
\text { space in the country }\end{array}$ \\
\hline & & & Japan Masjid Finder App & Private investors & $\begin{array}{l}\text { Muslim-Friendly Guide } \\
\text { Over } 200 \text { prayer spaces, as well as restaurants and hotels }\end{array}$ \\
\hline & & & Have Halal Will travel 2016 & Private investors & $\begin{array}{l}\text { Halal trip planner, offering the routes with the most } \\
\text { Muslim-friendly services and establishments }\end{array}$ \\
\hline
\end{tabular}


Table 2. Cont.

\begin{tabular}{|c|c|c|c|c|c|}
\hline Country & $\begin{array}{l}\text { Ranking Position } \\
\text { Comparison }\end{array}$ & $\begin{array}{l}\text { Percentage of Muslims } \\
\text { in Population }\end{array}$ & $\begin{array}{l}\text { Apps Websites } \\
\text { Muslim-Friendly }\end{array}$ & Body & Function \\
\hline \multirow{3}{*}{ Taiwan } & \multirow{3}{*}{$\begin{array}{l}2017 \text { 7th } \\
20185 \text { th }\end{array}$} & \multirow{3}{*}{$0.3 \%$} & Taiwan halal Apps & The official International Halal Taiwan & \multirow{3}{*}{$\begin{array}{l}\text { Displays the companies that participate in the Taiwan } \\
\text { International Halal Expo } \\
\text { Search for prayer spaces and Halal food, restaurants and } \\
\text { hotels, connecting to Taiwan's Muslim community } \\
\text { You can get halal travel suggestions and the latest } \\
\text { Muslim-friendly Environments }\end{array}$} \\
\hline & & & Halal.TW App & Taiwan university students & \\
\hline & & & $\begin{array}{l}\text { Taiwan Tourism Bureau } \\
\text { website-Muslim-friendly }\end{array}$ & Taiwan Tourism Bureau & \\
\hline \multirow[t]{2}{*}{ Australia } & \multirow[t]{2}{*}{$\begin{array}{l}2017 \text { 14th } \\
2018 \text { 10th }\end{array}$} & \multirow[t]{2}{*}{$3 \%$} & Halal Advisor & Private investors & \multirow{2}{*}{$\begin{array}{l}\text { Over 2,000 halal restaurants, Australia's top halal food } \\
\text { application, includes the option of take-away food } \\
\text { Guide to restaurants, markets and mosques, a list of over } \\
\text { 20,000 establishments in Australia, USA, Europe, } \\
\text { Singapore, Hong Kong and Africa }\end{array}$} \\
\hline & & & Zabihah & Private investors & \\
\hline \multirow[t]{2}{*}{ Canada } & \multirow[t]{2}{*}{2017 19th } & \multirow[t]{2}{*}{$3.2 \%$} & Scan Halal App & Private investors & \multirow{2}{*}{$\begin{array}{l}\text { Identifies the sources of the ingredients (plant, animal, } \\
\text { synthetic, etc). Over 750,000 products. } \\
\text { Over 15,000 restaurants in Canada, South Korea and the } \\
\text { USA }\end{array}$} \\
\hline & & & The Crave Halal app & Private investors & \\
\hline \multirow[t]{2}{*}{ Spain } & \multirow[t]{2}{*}{$\begin{array}{l}2017 \text { 9th } \\
201812 \text { th }\end{array}$} & \multirow[t]{2}{*}{$4 \%$} & Online Halal Guide & $\begin{array}{l}\text { Turespaña, the public body for } \\
\text { marketing tourism in Spain }\end{array}$ & \multirow{2}{*}{$\begin{array}{l}\text { In several languages, including Arabic, it aims to help } \\
\text { Muslim tourists to locate prayer spaces and halal services } \\
\text { in Spain } \\
\text { Aims to provide information about Halal tourism services } \\
\text { that have been certified by the Instituto Halal in Spain }\end{array}$} \\
\hline & & & $\begin{array}{l}\text { The Halal International } \\
\text { Tourism website } 2015\end{array}$ & Instituto Halal and InnovaTaxFree Group & \\
\hline $\begin{array}{l}\text { New } \\
\text { Zealand }\end{array}$ & $\begin{array}{l}2017 \text { 23th } \\
2018 \text { 20th }\end{array}$ & $1.1 \%$ & $\begin{array}{l}\text { Halal Guide for New Zealand } \\
\text { Tourism }\end{array}$ & $\begin{array}{l}\text { Tourism New Zealand, in association } \\
\text { with the Federation of Islamic } \\
\text { Associations of New Zealand (FIANZ) } \\
\text { and the Kiwi Muslim Directory }\end{array}$ & $\begin{array}{l}\text { Halal restaurants, hotels, supermarkets and grocery } \\
\text { stores, illustrated with photos of the most typical dishes } \\
\text { of several regions, in order to promote their local } \\
\text { products, such as lamb and cheeses, to the Muslim world } \\
\text { and thus increase exports }\end{array}$ \\
\hline \multirow[t]{2}{*}{$\begin{array}{l}\text { South } \\
\text { Africa }\end{array}$} & \multirow[t]{2}{*}{$\begin{array}{l}\text { 2017 4th } \\
20187 \text { th }\end{array}$} & \multirow[t]{2}{*}{$2 \%$} & $\begin{array}{l}\text { South African Muslim } \\
\text { Directory app } 2018\end{array}$ & $\begin{array}{l}\text { Not financed by any group, organization } \\
\text { or government but rather by the } \\
\text { advertisers and commercial sponsors. }\end{array}$ & Online guide to all the country's Muslim-friendly places \\
\hline & & & $\begin{array}{l}\text { Halal Tourism Basic } \\
\text { Guidelines and Glossary } 2018\end{array}$ & $\begin{array}{l}\text { Cape Town Tourism (CTT) } \\
\text { commissioned the project team led by } \\
\text { CrescentRatingPte Ltd }\end{array}$ & $\begin{array}{l}\text { Guide to inform the country's companies about the needs } \\
\text { of the Muslim market segment and its economic } \\
\text { importance }\end{array}$ \\
\hline
\end{tabular}

Source: own elaboration. 
Japan has climbed two positions, probably because it promotes its food (despite the fact that it does not have much to offer that is halal) by suggesting alternatives, such as vegetarian restaurants and restaurants specializing in fish and seafood, and this has helped it to improve its position in the ranking. Taiwan has climbed from seventh to fifth as a result of the efforts made by its public tourism board, which promotes, on its website, the companies and products that participate in the Taiwan International Halal Expo. It also provides apps that make it easier for Muslim tourists to stay in Taiwan.

Both Australia and Canada have improved their rankings by four positions, since they have great Muslim-friendly digital services. These are provided by private companies that manage the websites and applications promoting the local and international Muslim-friendly offering.

New Zealand has improved its ranking in the list of the 20 most Muslim-friendly countries of the non-Muslim-majority countries, benefiting from its online Muslim-friendly guide. This guide was prepared by the official tourist board to promote its products and increase exports of food, including lamb, cheese and kiwi, to Muslim countries.

On the other hand, countries that provide few such services have dropped down the ranking considerably. In Spain's case, it should be emphasized that it has many resources that can attract the Muslim market segment, including the monuments dating from the time of al-Ándalus (the area of Spain conquered by Muslims). Although it is the second most-visited country for worldwide tourism, between 2017 and 2018 Spain dropped down three positions in the rankings of Muslim-friendly countries to twelfth. South Africa has also come down the rankings because it lacks Muslim-friendly online services (see Tables 1 and 2). However, it clearly realized this, and in 2018 it created some services which helped it to recover its position in the 2019 ranking.

Of all the countries studied (see Table 2), it stands out that those that have risen in the ranking, despite not having a great Muslim-friendly offering, are those whose official bodies have launched online platforms to communicate with the Muslim market segment and promote themselves as destinations before such platforms were created by private bodies.

\section{Discussion and Conclusions}

Tourist destinations have a critical need to understand tourism and consumer experiences. We can state that there is a new generation of tourists who are forcing destinations to evolve in their direction to meet their needs and expectations [7] and depend on their mobile phones while traveling [97]. Destinations should promote applications as the preferred means of buying online and formulating appropriate strategies [98], since digital technologies make possible an efficient and sustainable public-private-consumer collaboration $[99,100]$; the use of ICT helps people who plan vacations to obtain detailed information, which gives them security and facilitates decision-making [101]. This will help ensure they enjoy the destination and can interact well with the local population $[29,102,103]$. It can therefore be said that online services suitable for Muslims are important for a country to achieve a good position in the ranking of Muslim-friendly destinations and to be able to attract that segment.

Ever increasing numbers of tourists use their mobile phones, not only to plan the journey and make reservations but also to increase their enjoyment of the trip [98]. Destinations should therefore promote applications as one of the preferred methods for purchasing online and formulating appropriate strategies [99].

Additionally, the growing number of people travelling internationally makes it essential for destinations to diversify their tourism offering, ensuring that they adapt to the needs of the market segments with greatest growth potential. Dialogue with tourists and product promotion should not only take place face to face at the destination but also online, and with new technologies exclusive channels may also be used.

One of the novel aspects of this work is its focus on the Muslim segment. This market segment is increasing because it is young and has considerable spending capacity. This has led the most sustainable and smart countries to adapt their services to the religious and cultural needs of the Muslim market segment, thus becoming Muslim-friendly destinations. 
Countries that have Muslim-friendly products and services should use the channels provided by ICTs to promote them [89], since Muslim-friendly online sites help tourists decide when choosing their destination and they allow them to plan and enjoy their trips [104]. Specialized applications also allow restaurants and hotels to provide information about their Muslim-friendly services through an exclusive channel without having to show their Halal certificates on the premises [96]. These online sites thus help destinations to promote their products and therefore increase their exposure to Muslim-majority countries.

For a country to be well-positioned in the ranking of Muslim-friendly destinations and therefore be able to attract the Muslim segment, it must necessarily have digital resources aimed at that segment. According to the analyses in this study, it is advisable that official bodies be the first to invest in the Muslim market segment so that private tourism companies realize its potential and react by providing Muslim-friendly services. In turn, the more Muslim-friendly offerings are provided, the more technology companies will launch digital platforms and mobile apps promoting the country and its Muslim-friendly tourism offering. Muslim-friendly applications help promote a country's products and therefore its international trade.

Becoming a smart, Muslim-friendly destination makes the country more sustainable as the apps and services can be used by Muslims living in the country, who are usually ignored by companies as they are a minority segment.

There is increased interest in researching how to attract the Muslim market segment and the best way to become a Muslim-friendly country, but one of the novel aspects of this study is its focus on digital technologies. This is therefore the first study to focus on the digital Muslim-friendly offering as a prerequisite to being most fully and efficiently a sustainable, smart Muslim-friendly destination. Another novel aspect of this study is the analysis of the nine sustainable smart tourist destinations with outstanding rankings in 2017 and 2018.

Future lines of research could analyze a more extended period by adding in the data for 2019 . Similarly, by increasing the number of sustainable smart Muslim-friendly tourism destinations to 25 or 30. Finally, future studies could apply these concepts to other market segments.

Author Contributions: This paper is part of the PhD project of. F.B.; "Conceptualization, F.B. and P.C-V.; methodology, F.B. and P.C-V; formal analysis, P.C-V.; F.B. and E.N-B.; investigation, P.C-V. and F.B.; resources, F.B.; writing-original draft preparation, F.B.; writing-review and editing, P.C-V.; F.B. and E.N-B.; visualization, P.C-V.; F.B. and E.N-B.; supervision, P.C-V. All authors have read and agreed to the published version of the manuscript.", please turn to the CRediT taxonomy for the term explanation. Authorship must be limited to those who have contributed substantially to the work reported.

Funding: This research received no external funding.

Conflicts of Interest: The authors declare no conflict of interest.

\section{References}

1. Mathews, S.; Bianchi, C.; Perks, K.J.; Healy, M.; Wickramasekera, R. Internet marketing capabilities and international market growth. Int. Bus Rev. 2016, 25, 820-830. [CrossRef]

2. Ferrero, R.; Beattie, E.; Phoenix, J. Sensor city-A global innovation hub for sensor technology. IEEE Instrum. Meas. Mag. 2018, 21, 4-16. [CrossRef]

3. Law, R.; Buhalis, D.; Cobanoglu, C. Progress on information and communication technologies in hospitality and tourism. Int. J. Contemp. Hosp. Manag. 2014, 26, 727-750. [CrossRef]

4. Ghaderi, Z.; Hatamifar, P.; Henderson, J.C. Destination selection by smart tourists: The case of Isfahan, Iran. Asia Pacific J. Tour. Res. 2018, 23, 385-394. [CrossRef]

5. Semerádová, T.; Vávrová, J.N. Using a systemic approach to assess Internet marketing communication within hospitality industry. Tour. Manag. Perspect. 2016, 20, 276-289. [CrossRef]

6. Lyu, S.O.; Hwang, J. Are the days of tourist information centers gone? Effects of the ubiquitous information environment. Tour Manag. 2015, 48, 54-63. [CrossRef]

7. Dickinson, J.E.; Hibbert, J.F.; Filimonau, V. Mobile technology and the tourist experience: (Dis)connection at the campsite. Tour Manag. 2016, 57, 193-201. [CrossRef] 
8. Michel, F. Désirs D'ailleurs: Essai D'anthropologie des Voyages; Presses de l'Université Laval: Québec, QC, Canada, 2005; p. 366.

9. Guédron, M.; Franck, M. Désirs d'ailleurs. Essai d'anthropologie des voyages, Préface de Jean-Didier, 2000. Hommes Migr 2000, 1226, 122-124.

10. Soldatenko, D.; Backer, E. A content analysis of cross-cultural motivational studies in tourism relating to nationalities. J. Hosp. Tour. Manag. 2019, 38, 122-139. [CrossRef]

11. Fischer, J. Markets, religion, regulation: Kosher, halal and Hindu vegetarianism in global perspective. Geoforum 2016, 69, 67-70. [CrossRef]

12. Huang, S.; Crotts, J. Relationships between Hofstede's cultural dimensions and tourist satisfaction: A cross-country cross-sample examination. Tour. Manag. 2019, 72, 232-241. [CrossRef]

13. Prayag, G.; Disegna, M.; Cohen, S.A.; Yan, H. Segmenting Markets by Bagged Clustering. J. Travel Res. 2015, 54, 234-250. [CrossRef]

14. Yang, Y.; Liu, H.; Li, X. The World Is Flatter? Examining the Relationship between Cultural Distance and International Tourist Flows. J. Travel Res. 2019, 58, 224-240. [CrossRef]

15. OMT-UNWTO. Panorama OMT del turismo internacional Edición 2018. Panorama OMT del turismo internacional Edición 2018. World Tourism Organization (UNWTO). Available online: https://www.e-unwto. org/doi/book/10.18111/9789284419890 (accessed on 16 February 2020).

16. Yoo, J.J.E.; McKercher, B.; Mena, M. A Cross-Cultural Comparison of Trip Characteristics. J. Travel Tour. Mark. 2004, 16, 65-77. [CrossRef]

17. Jung, T.H.; Lee, H.; Chung, N.; tom Dieck, M.C. Cross-cultural differences in adopting mobile augmented reality at cultural heritage tourism sites. Int. J. Contemp. Hosp. Manag. 2018, 30, 1621-1645. [CrossRef]

18. Sizoo, S.; Iskat, W.; Plank, R.; Serrie, H. Cross-Cultural Service Encounters in the Hospitality Industry and the Effect of Intercultural Sensitivity on Employee Performance. Int. J. Hosp. Tour. Adm. 2004, 4, 61-77. [CrossRef]

19. Bhatti, O.K.; Aslam, U.S.; Hassan, A.; Sulaiman, M. Employee motivation an Islamic perspective. Humanomics 2016, 32, 33-47. [CrossRef]

20. Widyaningrum, N.; Yu, J. Tobacco Use among the Adult Muslim Population in Indonesia: A Preliminary Study on Religion, Cultural, and Socioeconomic Factors. J. Drug Issues 2018, 48, 676-688. [CrossRef]

21. Mohsin, A. Tourist attitudes and destination marketing-The case of Australia's Northern Territory and Malaysia. Tour. Manag. 2005, 26, 723-732. [CrossRef]

22. Ryan, C. Halal tourism. Tour. Manag. Persp. 2016, 19, 121-123. [CrossRef]

23. Boğan, E.; Sarışık, M. Halal tourism: Conceptual and practical challenges. J. Islam Mark. 2019, 10, 87-96. [CrossRef]

24. Han, H.; Al-Ansi, A.; Olya, H.G.T.; Kim, W. Exploring halal-friendly destination attributes in South Korea: Perceptions and behaviors of Muslim travelers toward a non-Muslim destination. Tour. Manag. 2019, 71, 151-164. [CrossRef]

25. Garrigos-Simon, F.J.; Narangajavana-Kaosiri, Y.; Narangajavana, Y. Quality in Tourism Literature: A Bibliometric Review. Sustainability 2019, 11, 3859. [CrossRef]

26. Buhalis, D.; O'Connor, P. Information communication technology revolutionizing tourism. Tour. Recreat. Res. 2015, 30, 7-16.

27. Aurélien, D.; Desiré, R. An Evaluation of Destination Management Systems in Madagascar with Aspect of Tourism Sector'. Am. J. Ind. Bus Manag. Sci. Res. Publ. 2014, 4, 9. [CrossRef]

28. Alaei, A.R.; Becken, S.; Stantic, B. Sentiment Analysis in Tourism: Capitalizing on Big Data. J. Travel Res. 2019, 58, 175-191. [CrossRef]

29. Jovicic, D.Z. From the traditional understanding of tourism destination to the smart tourism destination. Curr. Issues Tour. 2019, 22, 276-282. [CrossRef]

30. Talón-Ballestero, P.; García-Muiña, F.E.; Rienda-Gómez, J.J.; González-Serrano, L. Repeat Consumer Behavior on Smart P2P Tourism Platforms. Sustainability 2019, 11, 7082. [CrossRef]

31. Femenia-Serra, F.; Perles-Ribes, J.F.; Ivars-Baidal, J.A. Smart destinations and tech-savvy millennial tourists: Hype versus reality. Tour. Rev. 2019, 74, 63-81. [CrossRef]

32. Gretzel, U.; Zhong, L.; Koo, C.; Cacho, A.; Mendes-Filho, L.; Estaregue, D.; Alves, C.; Moura, B.; Cacho, N.; Lopes, F. Mobile tourist guide supporting a smart city initiative: A Brazilian case study. Int. J. Tour. Cities 2016, 2, 164-183. 
33. Lepkowska-White, E.; Parsons, A. Strategies for monitoring social media for small restaurants. J. Foodserv. Bus Res. 2019, 22, 351-374. [CrossRef]

34. Wang, X.; Li, X.R.; Zhen, F.; Zhang, J. How smart is your tourist attraction? Measuring tourist preferences of smart tourism attractions via a FCEM-AHP and IPA approach. Tour. Manag. 2016, 54, 309-320. [CrossRef]

35. Xiang, Z.; Magnini, V.P.; Fesenmaier, D.R. Information technology and consumer behavior in travel and tourism: Insights from travel planning using the internet. J. Retail. Consum. Serv. 2015, 22, 244-249. [CrossRef]

36. Hornecker, E.; Bartie, P. Technology in Tourism: Handheld Guide Systems and Museum Technologies; Human Interface Technology Laboratory New Zealand: Christchurch, New Zealand, 2006.

37. Ruíz, M.A.C.; Bohorquez, S.T.; Molano, J.I.R. Colombian tourism: Proposal app to foster smart tourism in the country. Adv. Sci. Lett. 2017, 23, 10533-10537. [CrossRef]

38. Mang, C.F.; Piper, L.A.; Brown, N.R. The Incidence of Smartphone Usage among Tourists. Int. J. Tour. Res. 2016, 18, 591-601. [CrossRef]

39. Oh, S.; Lehto, X.Y.; Park, J. Travelers' intent to use mobile technologies as a function of effort and performance expectancy. J. Hosp. Leis. Mark. 2009, 18, 765-781. [CrossRef]

40. Xu, F.; Huang, S.; Li, S. Time, money, or convenience: What determines Chinese consumers' continuance usage intention and behavior of using tourism mobile apps? Int. J. Cult. Tour. Hosp. Res. 2019, 13, $288-302$. [CrossRef]

41. Kim, M.J.; Chung, N.; Lee, C.K.; Preis, M.W. Motivations and Use Context in Mobile Tourism Shopping: Applying Contingency and Task-Technology Fit Theories. Int. J. Tour. Res. 2015, 17, 13-24. [CrossRef]

42. Wang, D.; Xiang, Z.; Fesenmaier, D.R. Smartphone use in everyday life and travel. J. Travel Res. 2016, 55, 52-63. [CrossRef]

43. Garcia-Madariaga, J.; Recuero Virto, N.; Blasco López, M.F.; Aldas Manzano, J. Optimizing website quality: The case of two superstar museum websites. Int. J. Cult. Tour. Hosp. Res. 2019, 13, 16-36. [CrossRef]

44. Dickinson, J.E.; Ghali, K.; Cherrett, T.; Speed, C.; Davies, N.; Norgate, S. Tourism and the smartphone app: Capabilities, emerging practice and scope in the travel domain. Curr. Issues Tour. 2014, 1, 84-101. [CrossRef]

45. Rasinger, J.; Fuchs, M.; Höpken, W. Information Search with Mobile Tourist Guides: A Survey of Usage Intention. Inf. Technol. Tour. 2007, 9, 177-194. [CrossRef]

46. Vecchio PDel Mele, G.; Ndou, V.; Secundo, G. Creating value from Social Big Data: Implications for Smart Tourism Destinations. Inf. Process. Manag. 2018, 54, 847-860. [CrossRef]

47. Del Chiappa, G.; Baggio, R. Knowledge transfer in smart tourism destinations: Analyzing the effects of a network structure. J. Destin. Mark. Manag. 2015, 4, 145-150. [CrossRef]

48. Pine, B.J.; Gilmore, J.H. Welcome to the experience economy. Harv. Bus Rev. 1998, 76, 97-105. [PubMed]

49. Neuhofer, B.; Buhalis, D.; Ladkin, A. Smart technologies for personalized experiences: A case study in the hospitality domain. Electron. Mark. 2015, 17, 243-254. [CrossRef]

50. Gomez-Oliva, A.; Alvarado-Uribe, J.; Parra-Meroño, M.C.; Jara, A.J. Transforming Communication Channels to the Co-Creation and Diffusion of Intangible Heritage in Smart Tourism Destination: Creation and Testing in Ceutí (Spain). Sustainability 2019, 11, 3848. [CrossRef]

51. Simpura, J. Trends in alcohol consumption and drinking patterns: Sociological and economic explanations and alcohol policies. Nord. Stud. Alcohol. Drugs 2001, 18, 3-13. [CrossRef]

52. Talay, M.B.; Akdeniz, M.B.; Obal, M.; Townsend, J.D. Stock Market Reactions to New Product Launches in International Markets: The Moderating Role of Culture. J. Int. Mark. 2019, 27, 81-98. [CrossRef]

53. Kim, M.Y.; Moon, S.; Iacobucci, D. The Influence of Global Brand Distribution on Brand Popularity on Social Media. J. Int. Mark. 2019, 27, 22-38. [CrossRef]

54. Reisinger, Y.; Turner, L. Cross-cultural differences in tourism: A strategy for tourism marketers. J. Travel Tour. Mark. 1998, 7, 79-106. [CrossRef]

55. Philip, K.; John, T.; Bowe, J.; Makens, C. Marketing Turístico; traducción, Gestión Editorial Avanzada; Revisión Técnica, Javier Alfonso de Esteban Curiel, Rocío Samino García, 6th ed.; Pearson: Madrid, Spain, 2015.

56. Valiñas, R.F. Segmentación de Mercados; International Thomson Editores: Mexico City, Mexico, 2002.

57. Ali, A.; Xiaoling, G.; Sherwani, M.; Ali, A. Antecedents of consumers' Halal brand purchase intention: An integrated approach. Manag. Decis. 2018, 56, 715-735. [CrossRef]

58. Watkins, L.; Gnoth, J. The value orientation approach to understanding culture. Ann. Tour. Res. 2011, 38, 1274-1299. [CrossRef] 
59. Ahmed, W.; Najmi, A.; Faizan, H.M.; Ahmed, S. Consumer behaviour towards willingness to pay for Halal products: An assessment of demand for Halal certification in a Muslim country. Br. Food J. 2019, 121, 492-504. [CrossRef]

60. Ali, M.Y.; Ahmed, P.K.; Singh, S.N. Muslim Consumers' Halal Product Choice Behaviour: An Eye-Tracking Investigation on Visual Choice Process. In Academy of Marketing Science World Marketing Congress; Springer: Cham, Switzerland, 2017; pp. 137-152. [CrossRef]

61. Chandia, M.; Soon, J.M. The variations in religious and legal understandings on halal slaughter. Br. Food J. 2018, 120, 714-730. [CrossRef]

62. Giese, C. Kommentar I zum Fall: Heparin für Muslime - Wissenslücke: Nicht vegan und nicht halal. Ethik der Medizin. 2019, 31, 83-86. [CrossRef]

63. Pepis, S.; de Jong, P. Effects of Shariah-compliant business practices on long-term financial performance. Pacific-Basin Financ. J. 2019, 53, 254-267. [CrossRef]

64. Warren, S. YourAverageMuslim: Ruptural geopolitics of British Muslim women's media and fashion. Polit. Geogr. 2019, 69, 118-127. [CrossRef]

65. Alzeer, J.; Rieder, U.; Hadeed, K.A. Rational and practical aspects of Halal and Tayyib in the context of food safety. Trends Food Sci. Technol. 2018, 71, 264-267. [CrossRef]

66. Rahman, M.K.; Zailani, S.; Musa, G. Tapping into the emerging Muslim-friendly medical tourism market: Evidence from Malaysia. J. Islam Mark. 2017, 8, 514-532. [CrossRef]

67. Wingett, F.; Turnbull, S. Halal holidays: Exploring expectations of Muslim-friendly holidays. J. Islam Mark. 2017, 8, 642-655. [CrossRef]

68. Li, M. Cross-Cultural Tourist Research: A Meta-Analysis. J. Hosp. Tour. Res. 2014, 38, 40-77. [CrossRef]

69. Fourie, J.; Rosselló, J.; Gallego, M. Religion, Religious Diversity and Tourism. Kyklos 2015, 68, 51-64. [CrossRef]

70. Pew Research Center. Religious Landscape the Changing Global Religious Landscapehe 2017. Available online: http://www.swissworld.org (accessed on 1 September 2019).

71. Battour, M. Muslim Travel Behavior in Halal Tourism. Mobilities, Tourism and Travel Behavior-Contexts and Boundaries, Leszek Butowski, IntechOpen. 2017. Available online: https://www.intechopen.com/books/ mobilities-tourism-and-travel-behavior-contexts-and-boundaries/muslim-travel-behavior-in-halal-tourism (accessed on 27 February 2020). [CrossRef]

72. Masudin, I.; Fernanda, F.W.; Widayat, W. Halal Logistics Performance and Customer Loyalty: From the Literature Review to a Conceptual Framework. Int. J. Technol. 2018, 9, 1072. [CrossRef]

73. Choi, N.H.; Rahman, M.M. Muslim Consumer's Identification with and Loyalty to Halal Brand. J. Distrib. Sci. 2018, 16, 29-37. [CrossRef]

74. Licsandru, T.C.; Cui, C.C. Ethnic marketing to the global millennial consumers: Challenges and opportunities. J. Bus. Res. 2019, 103, 261-274. [CrossRef]

75. Mastercard; HalalTrip. Muslim Millennial Travel Report 2017. Available online: https://www.halaltrip.com/ halal-travel/muslim-millennial-travel-report (accessed on 16 February 2020).

76. Mastercard-Crescentrating. MasterCard-CrescentRating Global Muslim Travel Index 2017. Available online: https://www.crescentrating.com/reports/mastercard-crescentrating-global-muslim-travel-indexgmti-2017.html (accessed on 17 February 2020).

77. Pebriani, W.V.; Sumarwan, U.; Simanjuntak, M. The Effect of Lifestyle, Perception, Satisfaction, and Preference on the Online Re-purchase Intention. Indep. J. Manag. Prod. 2018, 9, 545. [CrossRef]

78. Lerner, M.Y. Connecting the Actual with the Virtual: The Internet and Social Movement Theory in the Muslim World-The Cases of Iran and Egypt. J. Muslim Minor. Aff. 2010, 30, 555-574. [CrossRef]

79. Baulch, E.; Pramiyanti, A. Hijabers on Instagram: Using Visual Social Media to Construct the Ideal Muslim Woman. Soc. Media Soc. 2018, 4, 1-15. [CrossRef]

80. Nusair, K.K.; Parsa, H.G.; Cobanoglu, C. Building a model of commitment for Generation Y: An empirical study on e-travel retailers. Tour. Manag. 2011, 32, 833-843. [CrossRef]

81. Xiang, Z.; Tussyadiah, I.; Buhalis, D. Smart destinations: Foundations, analytics, and applications. J. Destin. Mark. Manag. 2015, 4, 143-144. [CrossRef]

82. Fakhruroji, M. Digitalizing Islamic lectures: Islamic apps and religious engagement in contemporary Indonesia. Cont. Islam 2018, 13, 201. [CrossRef] 
83. Akhtar, N.; Sun, J.; Ahmad, W.; Akhtar, M.N. The effect of non-verbal messages on Muslim tourists' interaction adaptation: A case study of Halal restaurants in China. J. Destin. Mark. Manag. 2019, 11, 10-22. [CrossRef]

84. Yuen, Y.Y.; Yeow, P.H.P.; Lim, N. Internet banking acceptance in the united states and Malaysia: A cross-cultural examination. Mark. Intell. Plan. 2015, 33, 292-308. [CrossRef]

85. Filieri, R.; Alguezaui, S.; McLeay, F. Why do travelers trust TripAdvisor? Antecedents of trust towards consumer-generated media and its influence on recommendation adoption and word of mouth. Tour. Manag. 2015, 51, 174-185. [CrossRef]

86. Tan, G.W.H.; Ooi, K.B. Gender and age: Do they really moderate mobile tourism shopping behavior? Telemat. Inform. 2018, 35, 1617-1642. [CrossRef]

87. Campbell, H.A.; Altenhofen, B.; Bellar, W.; Cho, K.J. There's a religious app for that! A framework for studying religious mobile applications. Mob. Media Commun. 2014, 2, 154-172. [CrossRef]

88. Nisa, E.F. Social media and the birth of an Islamic social movement: ODOJ (One Day One Juz) in contemporary Indonesia. Indones. Malay World 2018, 46, 24-43. [CrossRef]

89. Yousaf, S.; Xiucheng, F. Halal culinary and tourism marketing strategies on government websites: A preliminary analysis. Tour. Manag. 2018, 68, 423-443. [CrossRef]

90. Isa, S.M.; Chin, P.N.; Mohammad, N.U. Muslim tourist perceived value: A study on Malaysia Halal tourism. J. Islam Mark. 2018, 9, 402-420. [CrossRef]

91. Mohsin, A.; Ryan, C. Business Visitors to the Northern Territory Expo. Tour. Recreat. Res. 1997, $22,67-69$. [CrossRef]

92. Weidenfeld, A. Religious Needs in the Hospitality Industry. Tour. Hosp. Res. 2006, 6, 143-159. [CrossRef]

93. Weidenfeld, A.; Ron, A.S. Religious needs in the tourism industry. Anatolia 2008, 19, 357-361. [CrossRef]

94. Mastercard and crescent rating. Digital Muslim Travel Report 2018. Available online: https://www. crescentrating.com/reports/digital-muslim-travel-report-2018.html (accessed on 17 February 2020).

95. Bolifa El Gharbi, F.; Cuesta Valiño, P.; Loranca Valle, C. Razones para apostar por el turismo halal. Int. J. Sci. Manag. Tour. 2017, 3, 175-185.

96. Mastercard-CrescentRating. Global Muslim Travel Index 2019. Available online: https://www.crescentrating. com/reports/global-muslim-travel-index-2019.html (accessed on 16 February 2020).

97. Tavakoli, R.; Wijesinghe, S.N.R. The evolution of the web and netnography in tourism: A systematic review. Tour. Manag. Persp. 2019, 29, 48-55. [CrossRef]

98. Tan, G.W.H.; Lee, V.H.; Lin, B.; Ooi, K.B. Mobile Applications in Tourism: the Future of the Tourism Industry. In Industrial Management and Data Systems; Emerald Group Publishing Ltd.: Bingley, UK, 2017; pp. 560-581.

99. Gretzel, U. Intelligent systems in tourism. A Social Science Perspective. Ann. Tour. Res. 2011, 38, 757-779. [CrossRef]

100. Sanz-Ibáñez, C.; Lozano, S.; Anton Clavé, S. Brokers in a destination's knowledge networks. J. Destin. Mark. Manag. 2019, 11, 120-129. [CrossRef]

101. Stepchenkova, S.; Mills, J.E.; Jiang, H. Virtual Travel Communities: Self-Reported Experiences and Satisfaction. In Information and Communication Technologies in Tourism 2007; Springer: Vienna, Austria, 2007; pp. 163-174.

102. Dickinson, J.E.; Cherrett, T.; Hibbert, J.F.; Winstanley, C.; Shingleton, D.; Davies, N.; Speed, C. Fundamental challenges in designing a collaborative travel app. Transp. Policy 2015, 44, 28-36. [CrossRef]

103. Bec, A.; Moyle, B.; Timms, K.; Schaffer, V.; Skavronskaya, L.; Little, C. Management of immersive heritage tourism experiencs: A conceptual model. Tour. Manag. 2019, 72, 117-120. [CrossRef]

104. Mastercard-CrescentRating. Global Muslim Travel Index 2018 [Internet]. 2018 [cited 2020 Feb 16]. Available online: https://www.crescentrating.com/reports/mastercard-crescentrating-global-muslim-travel-indexgmti-2018.html (accessed on 16 February 2020).

(C) 2020 by the authors. Licensee MDPI, Basel, Switzerland. This article is an open access article distributed under the terms and conditions of the Creative Commons Attribution (CC BY) license (http://creativecommons.org/licenses/by/4.0/). 